\title{
Significance of metallothioneins in differential cadmium accumulation kinetics between two marine fish species
}

\author{
Le Croizier Gaël ${ }^{1,}$, Lacroix Camille ${ }^{2}$, Artigaud Sébastien ${ }^{1}$, Le Floch Stéphane ${ }^{2}$, Raffray Jean ${ }^{1}$, \\ Penicaud Virginie ${ }^{1}$, Coquillé Valérie ${ }^{1}$, Autier Julien ${ }^{1}$, Rouget Marie-Laure ${ }^{3}$, Le Bayon Nicolas ${ }^{4}$, \\ Lae Raymond ${ }^{1}$, De Morais Luis Tito ${ }^{1}$
}

${ }^{1}$ UBO, CNRS, UMR 6539, Lab Sci Environm Marin LEMAR,IRD,IFREMER, BP 70, F-29280 Plouzane, France.

${ }^{2}$ Ctr Documentat Res \& Expt Accidental Water Pollut, 715 Rue Alain Colas,CS 41836, F-29218 Brest 2, France.

${ }^{3}$ UBO, CNRS, UMS 3113, IUEM, F-29280 Plouzane, France.

${ }^{4}$ IFREMER, Unite Physiol Fonct Organismes Marins, LEMAR UMR 6539, Ctr Brest,Lab PFOM ARN, BP 70, F-29280 Plouzane, France.

*Corresponding author : Gaël Le Croizier, email address : gael.lecroizier@hotmail.fr

\begin{abstract}
:
Impacted marine environments lead to metal accumulation in edible marine fish, ultimately impairing human health. Nevertheless, metal accumulation is highly variable among marine fish species. In addition to ecological features, differences in bioaccumulation can be attributed to species-related physiological processes, which were investigated in two marine fish present in the Canary Current Large Marine Ecosystem (CCLME), where natural and anthropogenic metal exposure occurs. The European sea bass Dicentrarchus labrax and Senegalese sole Solea senegalensis were exposed for two months to two environmentally realistic dietary cadmium (Cd) doses before a depuration period. Organotropism (i.e., Cd repartition between organs) was studied in two storage compartments (the liver and muscle) and in an excretion vector (bile). To better understand the importance of physiological factors, the significance of hepatic metallothionein (MT) concentrations in accumulation and elimination kinetics in the two species was explored. Accumulation was faster in the sea bass muscle and liver, as inferred by earlier $\mathrm{Cd}$ increase and a higher accumulation rate. The elimination efficiency was also higher in the sea bass liver compared to sole, as highlighted by greater biliary excretion. In the liver, no induction of MT synthesis was attributed to metal exposure, challenging the relevance of using MT concentration as a biomarker of metal contamination. However, the basal MT pools were always greater in the liver of sea bass than in sole. This species-specific characteristic might have enhanced Cd biliary elimination and relocation to other organs such as muscle through the formation of more $\mathrm{Cd} / \mathrm{MT}$ complexes. Thus, MT basal concentrations seem to play a key role in the variability observed in terms of metal concentrations in marine fish species.
\end{abstract}




\section{Graphical abstract}

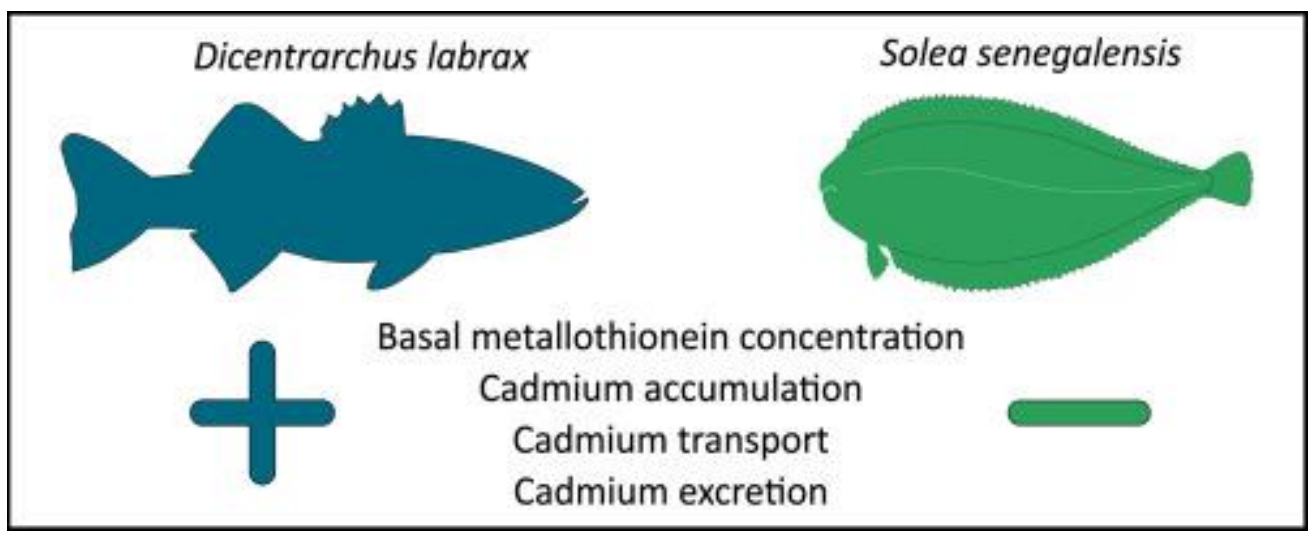

\section{Highlights}

- Environmentally realistic trophic $\mathrm{Cd}$ doses led to accumulation in edible marine fish. Faster accumulation occurred in the sea bass liver compared to the sole liver. Muscular Cd accumulation was also higher in sea bass than in sole. MT concentrations failed to reflect $\mathrm{Cd}$ exposure in both species. Species-specific basal MT pools seemed to be one of the physiological factors influencing Cd accumulation and elimination.

Keywords : Metal, Trace element, Dicentrarchus labrax, Solea senegalensis, Chronic dietary exposure 


\section{Introduction}

Contamination by heavy metals is a major problem that marine ecosystems have to face because they can be toxic even at very low concentrations. These inorganic elements are produced from natural processes, such as volcanic eruptions and natural crust erosion, but they can also result from anthropogenic inputs. This is the case for cadmium $(\mathrm{Cd})$, which is a common by-product of the mining industry and can be released at high amounts into the marine environment in some regions (World Health Organization, 2010). More precisely, it is estimated that one-third of the unintentional release of $\mathrm{Cd}$ is from the production and use of phosphate fertilizers (McGeer et al., 2011). Coastal regions in West Africa, which belong to the Canary Current Large Marine Ecosystem (CCLME), are therefore particularly subjected to $\mathrm{Cd}$ residue due to the direct release of phosphogypsum into water by the phosphate industry (Gaudry et al., 2007). In addition to natural enrichment due to hydrodynamic processes, such 
as upwelling, this important source of dissolved Cd (e.g., estimated at $240 \mathrm{t} \mathrm{Cd} \cdot \mathrm{yr}^{-1}$ off the coast of Morocco) leads to high Cd concentrations in the coastal environment (e.g. up to 1.63 $\mathrm{mg} \cdot \mathrm{Kg}^{-1}$ in surface sediments and up to $0.37 \mu \mathrm{g} \cdot \mathrm{L}^{-1}$ for dissolved $\mathrm{Cd}$ in the water of the Senegal coast, Diop et al., 2014, 2015) and subsequent strong uptake by phytoplankton communities in this region (Auger et al., 2015). Along with this direct accumulation by phytoplankton, bioaccumulation at higher trophic levels, such as fish, mainly occurs through dietary pathways (Mathews and Fisher, 2009; Creighton and Twining, 2010). The ingestion of contaminated preys (such as the bivalve Arca senilis wich can contain Cd concentrations of $26.1 \mu \mathrm{g} \cdot \mathrm{g}^{-1} \mathrm{ww}$, Bodin et al., 2013) can lead to significant accumulation in the organs of fish from this region (e.g. up to $0.16 \mathrm{mg} \cdot \mathrm{kg}^{-1}$ wet weight in the muscle of Pagellus acarne and up to $38.4 \mathrm{mg} \cdot \mathrm{kg}^{-1}$ dry weight in the liver of Sardinella aurita, El Morhit et al., 2013; Diop et al., 2016).

Among the different fish species, great variability in terms of metal accumulation is observed, resulting from different habitat occupation (Goutte et al., 2015) and/or different feeding habits (Le Croizier et al., 2016; Metian et al., 2013). This variability has also been observed between the CCLME species in different countries, such as Morocco (Chahid et al., 2014), Mauritania (Roméo et al., 1999; Sidoumou et al., 2005) or Senegal (Diop et al., 2016; Diop and Amara, 2016). However, these parameters may not be sufficient to explain the observed variability since species from the same habitat (Barhoumi et al., 2009; Siscar et al., 2013), or those that share the same trophic niche (Kiszka et al., 2015), can also present different amounts of accumulated metals. Therefore, there is a need to conduct experimental studies to free bioaccumulation measurements from ecological parameters. Under experimental conditions, accumulation may vary under environmental parameters, such as the food composition (Wang et al., 2012), temperature and salinity of water (Guinot et al., 2012; Zhang and Wang, 2007a) and duration and concentration of metal exposure (Berntssen et al., 2001; Long and Wang, 2005b), making comparisons between species difficult from one study to another. Relatively few authors have investigated the metal accumulation of different marine fish species exposed the same conditions. It was however shown that the interspecific variability that was observed in situ also occurred in controlled conditions (Jeffree et al., 2006; Kalman et al., 2010; Mathews et al., 2008).

Metals can take several months to accumulate, which implies the necessity of studying bioaccumulation over several months. Moreover, the metal concentration will vary depending 
on the organ considered. Following dietary exposure, the $\mathrm{Cd}$ concentration in fish will generally follow this order: intestine $>$ liver $\approx$ kidney $>$ gills $>$ muscle (Berntssen et al., 2001; Kim et al., 2006). Once ingested, Cd uptake occurs in intestinal tissue through membrane transporters, via channels for calcium or transporter proteins for essential trace metals. Dietary accumulation thus first takes place in the digestive tract. After reaching the liver, $\mathrm{Cd}$ is released into general blood circulation and finally attains secondary accumulation in organs, such as muscle. In fish, $\mathrm{Cd}$ is known to have a long biological half-life (e.g., more than a year in the liver and kidney in rainbow trout; Haux and Larsson, 1984), reflecting the poor efficiency of excretion pathways. Internal $\mathrm{Cd}$ depuration mainly occurs through urine production from the kidney and bile excretion from the liver to intestine and is finally eliminated with faeces (McGeer et al., 2011). Some authors have investigated Cd elimination, and differences were found between species (Mathews et al., 2008).

Cd toxicity is responsible for numerous impairments in organisms, such as oxidative damage, endocrine and ionoregulation disruption, histopathology and depression of the immune system, which can ultimately affect growth and survival (McGeer et al., 2011). Numerous physiological mechanisms are able to prevent this toxicity in fish. Among them, metallothioneins (MT) are one of the most well-known and described as well as one of the most ubiquitous mechanisms in the animal kingdom (Adam et al., 2010). MT are a group of low molecular weight (approximately $6 \mathrm{kDa}$ in fish) cytosolic proteins that are involved in metal sequestration. One of their main characteristics is the presence of a large number of thiol groups that are able to bind to divalent cations. The formation of this complex prevents $\mathrm{Cd}$ from remaining as a free ion, its most toxic form. MT are inducible in fish after metal exposure (Cheung et al., 2004; George et al., 1996); however, many experimental studies have used much higher concentrations than those found in the marine environment. In situ studies have shown positive correlations between $\mathrm{Cd}$ and MT concentrations, suggesting a strong relationship between the MT concentration and bioaccumulation for some fish (Fernandes et al., 2007, 2008). However, this relationship is highly species-specific since some fish present a high Cd concentration alongside low MT concentrations (Rosario Siscar et al., 2014).

The goal of our experiments was to compare $\mathrm{Cd}$ accumulation and elimination between two different marine fish species that are naturally present in the CCLME to better understand the variability of bioaccumulation within this Cd-exposed ecosystem. The European sea bass 
Dicentrarchus labrax is a demersal fish that is widely distributed in the Northeast Atlantic from the coasts of Norway to Morocco. This species inhabits estuaries, lagoons and coastal waters and displays a carnivorous diet that is composed of fish, crustaceans and cephalopods (López et al., 2015). On the other hand, the Senegalese sole Solea senegalensis is a benthic flatfish that is distributed from the Gulf of Biscay to the coasts of Senegal and also inhabits coastal waters and riverine estuaries. Due to its close association with the bottom, this species mainly feeds on benthic invertebrates, including crustaceans, polychaetes and bivalves (Teixeira and Cabral, 2010). In this study, fish were dietarily exposed to two environmentally realistic $\mathrm{Cd}$ concentrations based on the order of magnitude of the lowest (i.e. around 3.5 ppm) and the highest $\mathrm{Cd}$ level (i.e. around $25 \mathrm{ppm}$ ) previously reported in potential prey from the CCLME (Bodin et al., 2013; Maanan, 2008). We investigated Cd repartition between different organs: one of primary accumulation (liver), one of secondary accumulation (muscle) and a marker of excretion (bile). Since these two species can exhibit different biomarker responses to metallic contamination (Fonseca et al., 2011), we examined the possible induction of MT synthesis in the liver due to $\mathrm{Cd}$ exposure. Finally, we sought to explore the significance of the liver MT concentrations in regard to the accumulation and elimination kinetics of the two species.

\section{Materials \& Methods}

\section{Fish and experimental procedures}

All animal procedures were in accordance with the French and EU guidelines for animal research (project approval number: 03266.03).

Immature sea bass Dicentrarchus labrax used in this experiment were obtained from a commercial hatchery (Aquastream, Ploemeur, France), whereas immature Senegalese sole Solea senegalensis were provided from a marine farm (Ferme marine de 1'Adour, Anglet, France). The fish were transported to the Cedre (Centre of Documentation, Research and Experimentation on Accidental Water Pollution, Brest, France). After receiving anaesthesia by bathing in a $0.05 \mathrm{ml} / \mathrm{L}$ solution of tricaine methanesulfonate (MS-222) (Ackerman et al., 2005), each fish was randomly assigned to one of twelve high density polyethylene tanks that had a $300 \mathrm{~L}$ volume (six tanks for each species, 40 sole and 50 sea bass per tank to ensure equivalent biomass) at the Cedre's marine animal facility. This facility is an independent greenhouse that is submitted to a natural photoperiod and supplied with a continuous seawater 
flow from the bay of Brest. The temperatures in the experimental tanks followed the outdoor temperature.

Fish were first acclimated to the experimental conditions for one month, during which they were fed daily with dried commercial pellets (Turbot label rouge $1.4 \mathrm{~mm}$, Le Gouessant Aquaculture).

To obtain a low Cd $(3.5 \pm 0.2 \mathrm{ppm} \mathrm{dw})$ or high $\mathrm{Cd}(22.9 \pm 0.3 \mathrm{ppm} \mathrm{dw})$ concentration in fish food, the commercial pellets were spiked with a $10 \mathrm{mg} / \mathrm{L}$ or $100 \mathrm{mg} / \mathrm{L} \mathrm{Cd}$ (as $\mathrm{CdCl}_{2}$ in milliQ water) solution for $30 \mathrm{~min}$. The diet was then placed at $-20^{\circ} \mathrm{C}$, freeze dried and broken into small pellets before usage. The control diet was prepared in the same way, but with the addition of milliQ water only, where the measured background Cd level was $0.71 \pm 0.00 \mathrm{ppm}$ dw.

For each of the four conditions (i.e., Cd-exposed and control fish, for both species) there were three replicate tanks, and due to space limitations, the two experiments (i.e., low and high $\mathrm{Cd}$ exposure) were conducted separately. Low Cd exposure (hereafter experiment one) started first during summer 2014, whereas high Cd exposure (experiment two) started during summer 2015.

Dietary $\mathrm{Cd}$ exposure was initiated by randomly assigning three of the six tanks per species to Cd-enriched food. The six remaining tanks were fed the control diet. Cd exposure was conducted for 60 days for the two $\mathrm{Cd}$ concentrations, after which a depuration period was conducted that lasted for 30 days for the low $\mathrm{Cd}$ concentration (first experiment) and 60 days for the high Cd concentration (second experiment). During the depuration period, all of the tanks were fed the control diet.

Daily food distribution was performed slowly and continuously over $24 \mathrm{~h}$ with a clockwork feeder (COFA, Paris, France) to prevent pellets from remaining in the tank and thus avoid $\mathrm{Cd}$ desorption in water. Sea bass were fed at $1.7 \%$ body weight while sole were fed at $1 \%$ body weight per day to meet the physiological requirements of each species (Danion et al., 2011; Salas-Leiton et al., 2010). Despite differential food intake, Cd input was similar for both species relative to the liver weight (Table 1), which is the first organ of accumulation after crossing of the intestinal barrier. Fish were fasted for $48 \mathrm{~h}$ prior to each sampling to ensure the production of a sufficient bile volume. The bottom of each tank was siphoned every day to avoid Cd leaching from faeces.

\section{Monitoring and biological sampling}


Physico-chemical parameters $\left(\mathrm{O}_{2}, \mathrm{pH}\right.$, temperature, salinity) and water quality (nitrates, nitrites) were measured every ten days. During the first experiment (low Cd dose), the water temperature decreased from 19.8 to $12.7^{\circ} \mathrm{C}$, oxygen saturation increased from $76.3 \%$ to $88.6 \%, \mathrm{pH}$ increased from 7.8 to 8.1 and salinity increased from 34.9 to 35.6. During experiment two (high $\mathrm{Cd}$ dose), the water temperature decreased from 20.7 to $12.8^{\circ} \mathrm{C}$, oxygen saturation increased from $81.2 \%$ to $98.2 \%, \mathrm{pH}$ increased from 8.0 to 8.2 and salinity increased from 35.2 to 35.7. The water was free of nitrate and nitrite (Colorimetric test JBL) in both experiments.

Prior to initiating the dietary exposure treatment (T0), three fish per tank (nine for each condition) were anesthetized by bathing in a $0.05 \mathrm{ml} / \mathrm{L}$ solution of MS-222 before being euthanized by bathing in a $0.2 \mathrm{ml} / \mathrm{L}$ solution of MS-222. They were then weighed, measured (total length) and dissected with ceramic tools to avoid metal contamination. The liver, gallbladder and a piece of dorsal muscle (a standardized cut on the dorsal muscle) were collected. The liver was split into two samples, one for $\mathrm{Cd}$ analysis and one for metallothionein analysis, while other tissues were used for $\mathrm{Cd}$ analysis only. Samples were put in acid-washed $\left(10 \% \mathrm{HNO}_{3}\right)$ individual plastic microcentrifuge tubes, flash frozen in liquid nitrogen and stored at $-80^{\circ} \mathrm{C}$ until further analysis. The same sampling was performed after 10 (T10), 30 (T30) and 60 (T60) days of exposure. During the depuration period, the same was done after 10 (T70), 20 (T80) and 30 (T90) days for experiment one, as well as after 40 (T100), 50 (T110) and 60 (T120) days for experiment two.

After the first $\mathrm{Cd}$ exposure, mean total length $(\mathrm{cm})$ was 16.4 for control and 16.5 for exposed sea bass while 17.3 for control and 16.5 for exposed sole. Mean weight (g) was 41.7 for control and 44.0 for exposed sea bass while 53.3 for control and 49.1 for exposed sole.

After the second $\mathrm{Cd}$ exposure, mean total length $(\mathrm{cm})$ was 17.0 for control and 16.5 for exposed sea bass while 16.3 for control and 15.8 for exposed sole. Mean weight (g) was 50.1 for control and 42.2 for exposed sea bass while 46.0 for control and 38.8 for exposed sole.

\section{Cadmium analysis}

Liver samples for cadmium analysis were freeze-dried, ground, and stored in individual acidwashed plastic microcentrifuge tubes. Three liver samples of fish from the same tank were pooled to obtain approximately $90 \mathrm{mg}$ of dried sample, and they were digested in a mixture of $7 \mathrm{ml}$ of $70 \% \mathrm{HNO}_{3}$ and $1 \mathrm{ml}$ of $30 \% \mathrm{H}_{2} \mathrm{O}_{2}$ (both of ultrapure quality) in Teflon vessels. Mineralization was performed in a microwave oven (Ethos One, Milestone) for 15 min with increasing temperature until reaching $200{ }^{\circ} \mathrm{C}$, followed by $15 \mathrm{~min}$ at $200{ }^{\circ} \mathrm{C}(1500 \mathrm{~W})$ and 90 
min of cooling. The samples were then evaporated on a hotplate at $100{ }^{\circ} \mathrm{C}$, resolubilized with $2 \mathrm{ml}$ of $\mathrm{HNO}_{3}$, and diluted to $50 \mathrm{ml}$ with Milli-Q quality water (Merck Millipore). Because Cd levels are known to be lower in muscle tissues (Berntssen et al., 2001; Kim et al., 2006), the same procedure that was used for the liver was followed, but samples were pooled to obtain approximately $210 \mathrm{mg}$. For bile, the content of three gallbladders of individuals from the same tank were pooled to obtain approximately $150 \mathrm{mg}$ of wet sample.

Cadmium was analysed using an ICP Q-MS (X Series 2, Thermo Scientific) at the Pôle de Spectrométrie Océan (PSO, Plouzané, France) with an internal standard solution of rhodium. Reference materials (fish protein DORM-4 and lobster hepato-pancreas TORT-2, NRCC) were treated and analysed in the same way as samples. The results for the reference materials displayed mean cadmium recoveries of $97 \pm 16 \%$ for DORM- 4 and $99 \pm 15 \%$ for TORT-2. Blanks were included in each analytical batch. The concentrations in the liver (ppm), as well as in muscle (ppb), are provided on a dry weight basis $\left(\mu \mathrm{g} \cdot \mathrm{g}^{-1} \mathrm{dw}\right.$ and $\mathrm{ng} \cdot \mathrm{g}^{-1} \mathrm{dw}$, respectively), while those in bile (ppb) are expressed on a wet weight basis (ng. ${ }^{-1} \mathrm{ww}$ ). The detection limit $\left(\mathrm{ng} \cdot \mathrm{g}^{-1} \mathrm{dw}\right.$ ) was 0.2 for cadmium.

\section{Metallothionein analysis}

Analysis of metallothionein was performed on liver tissues, generally following the procedures described by Tenório-Daussat et al., 2014. Individual liver samples (approximately $200 \mathrm{mg}$ ) were homogenized in a solution $(250 \mu \mathrm{L}$ for the sole and $500 \mu \mathrm{L}$ for sea bass) containing Tris-HCl $20 \mathrm{mM} \mathrm{pH} \mathrm{8.6,0.01 \%} \mathrm{DTT} \mathrm{(dithiothreitol)} \mathrm{as} \mathrm{a} \mathrm{reducing} \mathrm{agent}$ and $1 \%$ antiproteolytic agent (Protease Inhibitor Mix, GE Healthcare). Samples were then centrifuged at $20.000 \times \mathrm{g}$ for $1 \mathrm{~h}$ at $4{ }^{\circ} \mathrm{C}$. Ten microlitres of supernatant was then separated from the pellet and heated at $70{ }^{\circ} \mathrm{C}$ for $10 \mathrm{~min}$. Another centrifugation step was conducted at $20.000 \times \mathrm{g}$ for $30 \mathrm{~min}$ at $4{ }^{\circ} \mathrm{C}$. The final supernatant containing MT was separated and frozen at $-80^{\circ} \mathrm{C}$ until analysis. The MT concentration was determined by spectrophotometry (Ellman's reaction), in which the sample absorbance was evaluated at $412 \mathrm{~nm}$ using a microplate reader spectrophotometer (POLARstar Omega, BMG LABTECH). Concentrations were estimated by using reduced glutathione (GSH) as an external standard. Ellman's reaction colours thiol groups, and since reduced GSH includes one thiol and MT from sea bass and sole includes 20 thiols, the MT content was calculated by using the relationship of $20 \mathrm{~mol}$ reduced GSH $=1 \mathrm{~mol}$ MT. Finally, the MT concentration (ppm) was expressed on a dry weight basis $\left(\mu \mathrm{g} \cdot \mathrm{g}^{-1} \mathrm{dw}\right)$ using the referenced molecular weight of sea bass MT (5992 Da; 
NCBI accession number: AAF22355) and sole MT (6051 Da; NCBI accession number: ADF42597).

\section{Data analysis}

Kinetic constants were calculated as the slope of the regression line of the $\mathrm{Cd}$ concentration over time, following the equation: $\mathrm{C}=k * \mathrm{t}+\mathrm{C}_{0}$ where $\mathrm{C}$ is the $\mathrm{Cd}$ concentration in the liver, $k$ is the kinetic constant (i.e. accumulation or efflux rate), $\mathrm{t}$ is the time and $\mathrm{C}_{0}$ is the initial $\mathrm{Cd}$ concentration in the liver (i.e. at $\mathrm{T} 0$ for the accumulation period and at $\mathrm{T} 70$ for the depuration period). An accumulation rate $\left(k_{\mathrm{a}}\right)$ was inferred for the two species when at least two sample points were significantly higher in exposed fish compared to control ones during the exposure period (i.e., for liver concentrations between T0 and T60 in both experiments). An efflux rate $\left(k_{\mathrm{e}}\right)$ was calculated when a significant decrease of the $\mathrm{Cd}$ levels occurred during the depuration period (i.e., in the liver for the highest exposure dose). The proportion of hepatic cadmium transported to muscle or excreted through bile was defined as the percentage of the ratio of the liver $\mathrm{Cd}$ concentration to the muscle or bile $\mathrm{Cd}$ concentration, calculated during the entire experiment. All of the data submitted to the statistical tests were first checked for normality (Shapiro-Wilks test) and homogeneity of variance (Bartlett test). When these conditions were verified, raw data were used; otherwise, they were transformed with a log function. One-way ANOVAs followed by Tukey's HSD tests were performed to test differences between groups. Analysis of covariance, ANCOVA, was used to compare the accumulation rates of the two species. All of the statistical analyses were performed using the free software R (R Core Team, 2016). Comparison of the MT (isoform 1) amino acid sequences of D. labrax and S. senegalensis was performed using the NCBI database.

\section{Results}

\section{Cd kinetics}

Muscle

During experiment one ( $3.5 \mathrm{ppm}$ exposure), the Cd concentrations in the muscle of exposed sea bass were significantly higher compared to those of control fish after T30 (ANOVA; $\mathrm{p}<0.05$ ) and reached $8.2 \pm 2.9 \mathrm{ppb}$ dw after 60 days (Fig. 1A). During the depuration period, the $\mathrm{Cd}$ concentrations remained similar to those of the exposure period, even after 30 days of depuration (T90), when the Cd level was $10.5 \pm 1.4 \mathrm{ppb} \mathrm{dw}$ in D. labrax. The accumulation 
pattern in Senegalese sole muscle was quite different (Fig. 1B). The Cd amounts were significantly higher in exposed fish compared to control fish only at the end of the 60 day exposure period (ANOVA; $\mathrm{p}<0.05$ ), with a mean of $8.3 \pm 4.0 \mathrm{ppb} \mathrm{dw}$.

In the second experiment (22.9 ppm exposure), muscle of exposed sea bass showed higher $\mathrm{Cd}$ concentrations compared to those of the control after 10 days and throughout the experiment (ANOVA; p<0.001), reaching $91.2 \pm 76.4 \mathrm{ppb} \mathrm{dw}$ (i.e., $18.2 \mathrm{ppb} w \mathrm{w}$ ) at T60 (Fig. 1C). Within exposed sea bass, the Cd levels were also always higher than that at T0 (ANOVA; $\mathrm{p}<0.05$ ), but did not vary following exposure. In sole muscle, the $\mathrm{Cd}$ amounts were higher in exposed fish compared to control fish from T60 to T120 (ANOVA; $\mathrm{p}<0.05$ ), with a maximum mean of $31.7 \pm 35.8 \mathrm{ppb} \mathrm{dw}$ (i.e., $6.3 \mathrm{ppb} \mathrm{ww}$ ) at T60, but neither varied during this period within exposed fish (Fig. 1D).

\section{Liver}

Following $3.5 \mathrm{ppm}$ exposure, the $\mathrm{Cd}$ concentrations in the sea bass liver were significantly higher in exposed fish compared to control fish from T30 to T90 (ANOVA; p<0.05) (Fig. 2A). Within exposed sea bass, the Cd concentrations from T30 to T90 were higher than at T0 and T30 (ANOVA; $\mathrm{p}<0.001$ ) and reached $3.6 \pm 1.5 \mathrm{ppm}$. In the sole liver, the $\mathrm{Cd}$ concentrations were significantly higher in exposed fish compared to control fish from T30 to T90 (ANOVA; p<0.05) (Fig. 2B). Within exposed sole, the Cd concentrations at T30, T60, T80 and T90 were higher than at T0 (ANOVA; $\mathrm{p}<0.05$ ) and reached $4.4 \pm 1.2 \mathrm{ppm}$. During the depuration period, a significant decrease occurred from T60 to T70.

Following 23.9 ppm exposure, the Cd kinetics in the liver showed the same pattern in the two species, although the Cd levels in exposed fish were significantly higher than in control fish earlier in sea bass (i.e., after 10 days of exposure) than in Senegalese sole (i.e., after 30 days of exposure) (ANOVA; p <0.001) (Fig. 2C, 2D). For both species, after 60 days of exposure (T60) and after T30 for sea bass, the Cd concentrations in the liver were significantly higher than those at T0 and T10 (ANOVA; p<0.001). Then, the Cd levels increased until T70 (i.e., 10 days after the end of exposure), when they significantly differed from those at T30 (ANOVA; p <0.05), reaching $20.2 \pm 9.7 \mathrm{ppm} \mathrm{dw}$ for sea bass and $17.2 \pm 1.7 \mathrm{ppm} \mathrm{dw}$ for Senegalese sole. During the elimination period, the Cd concentrations remained similar and only differed from T70 after 60 days of depuration (T120) in both species (ANOVA; $<<0.05$ ). $\mathrm{Cd}$ accumulation was linear over time in the liver for both species regardless of exposure dose. The accumulation rate $\left(k_{\mathrm{a}}\right)$ increased with the exposure dose for both species 
(ANCOVA, p <0.01) (Table 2). $k_{\mathrm{a}}$ was similar in the two species for the low exposure dose, whereas for the highest dose, it was superior in sea bass compared to sole $\left(k_{\mathrm{a}=} 0.24\right.$ and 0.13 , respectively, ANCOVA, p<0.01) (Fig. 3). The Cd concentrations over the depuration time were not linear and thus poorly fitted a linear regression, even after log-transformation of the raw values $\left(\mathrm{R}^{2}<0.31\right.$, not shown). Calculation of the efflux rate $\left(k_{\mathrm{e}}\right)$ was therefore considered to not be relevant. However, the elimination rate (\%) was used as a percentage decrease of the initial value (after 70 days). The proportion of removed $\mathrm{Cd}$ did not significantly differ between species (Table 2).

Bile

During experiment one (3.5 ppm exposure), the $\mathrm{Cd}$ concentrations measured in bile were only significantly higher in exposed sea bass compared to control fish (ANOVA, $\mathrm{p}<0.001$ ) at the end of the depuration period (T90), when they reached $73.7 \pm 2.1 \mathrm{ppb} w \mathrm{w}$ (Fig. 4A). No differences between exposed and control fish were found for Senegalese sole (Fig. 4B).

In experiment two (22.9 ppm exposure), for both species, the Cd levels in bile were higher in exposed fish compared to control fish (ANOVA, $\mathrm{p}<0.05$ for sea bass and $\mathrm{p}<0.01$ for sole) from 30 days of exposure to the end of the depuration period (T120), but no variation was found within exposed fish during this period (Fig. 4C, 4D). The maximum $\mathrm{Cd}$ amounts in bile were found at the end of the exposure period (T60), up to $117.2 \pm 64.3$ and $95.1 \pm 56.5 \mathrm{ppb}$ ww for sea bass and sole, respectively.

\section{Organotropism}

The Cd concentrations were always higher in the liver than in the muscle or bile of the two species in both experiments (ANOVA, $\mathrm{p}<0.001$ ). A higher proportion of hepatic Cd was transported to sea bass muscle compared to sole muscle for both experiments, while a higher proportion of hepatic Cd was excreted through sea bass bile only in experiment two (Fig. 5).

For sole, accumulation in exposed fish compared to control fish occurred earlier in the liver (from T30) than in muscle (at/from T60) in both experiments. In sea bass, accumulation in the two organs occurred simultaneously for the two exposure doses.

\section{Metallothioneins}

During experiment one (3.5 ppm Cd exposure), no difference in the MT concentration was observed in the liver of exposed fish compared to control fish for either species (Fig. 6A). In the meantime, the MT amounts in sea bass were always higher than those in Senegalese sole, 
whatever the condition, i.e., control or exposed fish (ANOVA, p<0.001). The MT concentrations changed over time for both species, but were more variable for sea bass. In sea bass, the concentrations ranged from $157.0 \pm 37.2$ to $342.5 \pm 57.7 \mathrm{ppm} \mathrm{dw}$, whereas in Senegalese sole, they were between $30.3 \pm 12.1$ and $104.9 \pm 53.0 \mathrm{ppm} \mathrm{dw}$.

During experiment two (23.9 ppm Cd exposure), significant difference in the MT concentration between exposed and control fish was only observed in S. senegalensis at T80 and T90 (ANOVA, p<0.05) (Fig. 6B).

Similarly, as in experiment one, the MT levels were generally higher in sea bass liver than in Senegalese sole liver (ANOVA, $\mathrm{p}<0.001$ ) except at T0 and T10. At T0, no differences were observed between species. At T10, the MT levels were higher in control sea bass (ANOVA, $\mathrm{p}<0.01$ ) and in exposed sea bass (ANOVA, $\mathrm{p}<0.05$ ) compared to control sole only. The MT levels varied over time for both species, but fluctuated much more for sea bass, from $141.6 \pm$ 53.0 to $325.8 \pm 96.0 \mathrm{ppm} \mathrm{dw}$, and from $58.5 \pm 20.1$ to $134.1 \pm 34.3 \mathrm{ppm}$ dw in Senegalese sole.

Finally, it should be noted that in the 60 amino acid sequence of the MT from D. labrax and S. senegalensis, 7 differences were found, including one major modification in the $34^{\text {th }}$ amino acid (serine/proline).

\section{Discussion}

The goal of our experiments was to compare $\mathrm{Cd}$ accumulation and elimination between two different marine fish species that are naturally found in the CCLME to better understand the bioaccumulation variability within this Cd-exposed ecosystem.

\section{Environmental relevance of the measured $\mathrm{Cd}$ and MT concentrations}

The bioaccumulated $\mathrm{Cd}$ concentrations found for both species in the present study were generally in the same order of magnitude as those observed in situ, supporting the environmental relevance of the exposure doses and duration used, although a few differences were observed. For instance, although the Cd levels in sea bass muscle were similar, the experimentally obtained concentrations in the liver were always above those found in the field (Table 3). Spiked diets, such as used in the present study, and diets with naturally incorporated metals can result in different assimilation efficiency (Harrison and Curtis, 1992). However, previous studies have shown that $\mathrm{Cd}$ was more bioavailable from prey with naturally incorporated $\mathrm{Cd}$ than from $\mathrm{Cd}$-soaped commercial diet (Ng and Wood, 2008; Wang 
et al., 2012), refuting a major implication of metal speciation in the higher hepatic $\mathrm{Cd}$ accumulation found in our study. As organotropism (i.e., metal repartition between organs) was shown to depend on the route of exposure (Chowdhury et al., 2005), the differences observed between field studies and our experimental conditions might be reflective of the greater diversity in the exposure pathways found in the natural environment (i.e. direct exposure in addition to trophic pathway). For even more realism, future experimental studies should consider both direct and trophic metal exposure. It is of interest to note that the maximum Cd levels that bioaccumulated in muscle $(0.006$ and $0.018 \mathrm{ppm}$ ww for sole and sea bass, respectively) after a 2-month exposure to food contaminated with environmentally relevant concentrations were below the current maximum acceptable limit for seafood set by the European Union, which is 0.05 ppm ww (Official Journal of the European Union, 2014). The MT concentrations found for both species were similar to those observed in wild fish, but lower than those found in cultured fish (Table 3). However, lower values were obtained by quantifying MT from the sea bass liver by spectrophotometry, as in our study, compared with liquid chromatography (Jebali et al., 2008) or polarography (Roméo et al., 1997). These results highlight that the observed variability in terms of the MT concentration between studies for a single species can be partly explained by the different analytical methods used.

\section{MT induction}

Binding sites are known to play a key role in the accumulation of metals in organisms which is the case for storage proteins, such as metallothioneins, for which gene transcription induction has been shown in marine fish after exposure to various metal ions, including $\mathrm{Cd}$ (Cheung et al., 2004; George et al., 1996). This induction may result in an increase of the MT concentration in tissues depending on the time considered and exposure type. In the sea bass liver, increase in MT levels has been shown $48 \mathrm{~h}$ after intraperitoneal injection (Jebali et al., 2008). In dietary studies involving exposure doses similar to those used in our study, increase in MT tissue concentration also occurred in other marine species (Berntssen et al., 2001; Dang and Wang, 2009). Due to this metal induction, MT are commonly used as a biomarkers of environmental contamination in fish species (Hauser-Davis et al., 2012b).

In the present study, metal exposure only led to a slight increase of the MT levels in the sole liver during the depuration period (i.e., T80 and T90) after feeding with the highest Cd concentration, which suggests that the basal hepatic pool of MT was high enough to sequestrate $\mathrm{Cd}$ ions, except for sole, in which de novo synthesis of MT was induced after the highest accumulated $\mathrm{Cd}$ level (i.e., 70 days after the beginning of the exposure). This 
hypothesis was supported by Dallinger et al. in 1997, who concluded that for a slight Cd increase, sequestration was achieved by displacement of essential metals, such as zinc and copper, from MT binding sites. Additional MT synthesis was thought to occur only for higher Cd concentrations to bind excess metal.

No increase in MT concentration following Cd administration was generally observed in the liver of the two species for both of the exposure doses used in our study. Indeed, metal exposure is not always followed by induction of de novo MT synthesis. This was the case for Gilt-head seabream Sparus aurata sampled in different fish farming systems, which showed contrasting Cd concentrations in the liver, but similar MT levels (Cretì et al., 2009). Increase in MT concentration seems to be species-dependent because 6 days after intraperitoneal injection, the MT levels increased three-fold over the basal values in the $S$. aurata liver, whereas they remained the same in S. senegalensis (Kalman et al., 2010). Conversely, MT synthesis can be influenced by environmental and endogenous factors related to season, gender and maturation (Hylland et al., 1998), as shown in S. senegalensis, for which the liver MT levels can vary with temperature (Siscar et al., 2014).

In our two experiments, the MT concentrations changed over time for both species, regardless of metal exposure or water parameters (i.e., $\mathrm{O}_{2}, \mathrm{pH}$, Temperature, Salinity; see Annex 1). Nevertheless, physical stresses, such as handling, are known to produce an elevation of physiological markers, such as the plasma cortisol and MT levels, in fish (Tort et al., 1996). In addition, cortisol has been identified as an endogenous inducer of MT synthesis (Fu et al., 1990; Hyllner et al., 1989). Outside sounds or cleaning of the tanks could thus have constituted stress sources, leading to the variability observed over time, inducing MT synthesis directly or indirectly via cortisol secretion in both exposed and control fish. Finally, the fact that the highest variability was observed for sea bass might be the result of its greater sensitivity due to its gregarious swimming behaviour and escape reactions in response to outside stimuli.

The fact that MT synthesis can be induced by various biotic and abiotic confounding factors implies that MT concentrations do not always reflect metal exposure and bioaccumulation in wild marine fish (Mieiro et al., 2011). The use of MT concentration as a biomarker of contamination should thus be considered with caution in the natural environment as well as in experimental conditions, where external factors may induce MT synthesis.

\section{MT significance in the fate of $\mathrm{Cd}$ in fish tissues}


While there is no doubt about the possible influence of metal exposure on the MT concentration, very few studies have investigated the role of MT in metal accumulation kinetics in marine fish. Moreover, the net metal accumulation in an aquatic organism is the result of a balance among three mechanisms: the accumulation rate $\left(k_{\mathrm{a}}\right)$ from the diet, accumulation rate of dissolved forms, and efflux rate. In marine fish, where metal influx from food has been shown to be dominant (Mathews and Fisher, 2009; Creighton and Twining, 2010), accumulation will be mainly dependent on the accumulation rate from food and the elimination rate.

\section{- Hepatic Cd uptake}

In fish, multiple routes for dietary Cd uptake along the gastrointestinal tract have been found. Among them, Cd ion passage through the intestinal wall is believed to occur via essential metal transporters, such as calcium, copper, iron and zinc channels (McGeer et al., 2011). Moreover, amino acid and small peptide transporters may also participate in the uptake of $\mathrm{Cd}$ conjugated to cysteine or cysteine-containing oligopeptides. Once in the bloodstream, $\mathrm{Cd}$ is primarily transported by plasma transport proteins in which MT are found, albeit in small proportion. The liver is the first organ that internalized metal will encounter, which gives it a primary role in $\mathrm{Cd}$ accumulation compared to other tissues, such as muscle, as observed in our species. The Cd concentrations in the liver of the two species were maximal 10 days after the end of the exposure period for the highest exposure dose. This offset might indicate a slight retention of $\mathrm{Cd}$ by the intestine before reaching the liver, as the intestine was shown to also accumulate Cd (Berntssen et al., 2001; Kim et al., 2006). Just as accumulation in the liver increased in a dose-dependent way, as shown in other fish species (Berntssen et al., 2001; Kim et al., 2006), the accumulation rate $\left(k_{\mathrm{a}}\right)$, calculated from the Cd concentrations in the liver increased with the exposure dose in the two species. The assimilation efficiency (AE), namely the portion of retained $\mathrm{Cd}$ following dietary ingestion, seems to be highly species-dependent since it can vary from 2 to $45 \%$ from one species to another (Mathews and Fisher, 2008; Zhang and Wang, 2007b). As a result, in experiment two, $k_{\mathrm{a}}$ in the sea bass liver was higher than in the sole liver, revealing faster accumulation in this species. This observation is unlikely to result from the slight higher food intake of the sea bass since AE has been shown to decrease with an increase in ingestion rate in the snapper Lutjanus argentimaculatus (Xu and Wang 2002). It might rather suggest that differences could exist in intestinal membrane metal transport between the two species, leading to greater AE in sea bass. This characteristic 
was confirmed by the significant accumulation compared to control fish that occurred after 10 days of exposure in sea bass and after 30 days in sole.

The hepatic MT levels were always higher in sea bass compared to sole regardless of the experiment, time or even conditions. In light of the above conclusions concerning MT induction, this greater MT pool would allow sea bass to support higher metal accumulation without triggering an induction of de novo MT synthesis. This interspecific difference in MT concentrations has been reported in the field without an obvious influence of the environment (Rosario Siscar et al., 2014). Furthermore, it seems that lower MT production can exist in flatfish compared to roundfish species for the same sampling area (Beg et al., 2015). Even if ecological features are involved, when overcoming environmental parameters, as in our study, different physiological responses can be related to metabolism and/or phylogenetic divergence. First, the higher metabolism in sea bass might imply higher requirements for essential metals, leading to the synthesis of more binding sites, including those for MT. Second, MT the biochemical properties can display significant phylogenetic dependence (Scudiero et al., 2005), which might involve different responses to the same environmental conditions. Concerning the species used in the present study, the variation observed in the MT sequence for the same protein isoform may imply a slight difference in terms of function, resulting in different regulation patterns as well as different basal concentrations. This hypothesis can partially explain the species-specificity, which might have been driven by contrasting ecological niches (i.e., demersal versus benthic). Finally, this species difference in MT levels could have been due to the life history of the fish, which did not come from the same origin and faced different farming conditions. Any previous influence of metal exposure on the starting MT levels can, however, be rejected, as sole showed the highest Cd concentration at T0, but the lowest MT basal pool.

In sum, the findings concerning the sea bass liver suggest an increase of the $\mathrm{Cd}$ accumulation rate alongside the MT concentrations, as previously found in the whole body of other species (Long and Wang, 2005a, 2005b). These authors concluded that metal sequestration by MT may prevent the inhibition of membrane transporters caused by metal toxicity, notably by reducing the activity of $\mathrm{Na}^{+} / \mathrm{K}^{+}$ATPase in the gills. In each of these studies, experiments were conducted on individuals from a same species, showing that MT can enhance Cd uptake in fish with similar physiological basis. In our study, the high MT levels observed in the sea bass liver may have also been found in enterocytes. Although both species have different physiologies and MT may not be the only factor that influences Cd uptake, this characteristic might provide more efficient metal detoxification and thus reduce the inhibition of subsequent 
Cd assimilation. It implies that species with the highest MT levels would be subjected to increased metal accumulation, as observed in field studies (Fernandes et al., 2008) and by the very high correlation $(\mathrm{r}=0.991)$ found between the $\mathrm{Cd}$ and MT concentrations in wild sea bass (Fernandes et al., 2007). In the natural environment it is however difficult to distinguish MT induction following metal exposure from a greater accumulation linked to high basal MT levels.

\section{- Cd efflux from the liver}

In fish, $\mathrm{Cd}$ depuration from the liver is the result of biliary excretion from the gallbladder to the intestine and is finally eliminated with faeces (McGeer et al., 2011). Biliary excretion was also dose-dependent and occurred after 30 days of exposure for both sea bass and sole for the highest exposure dose. Even if metal concentrations are known to be low in fish bile (Andréasson and Dave, 1995) and represent approximately only $1 \%$ of the $\mathrm{Cd}$ amount in the liver, the fast bile turnover (i.e. renewal after each digestion) led to a significant decrease of the $\mathrm{Cd}$ hepatic concentrations, with a mean loss of near 40 and $60 \%$ for sole and sea bass respectively (Table 2). Biliary excretion was thus an efficient pathway for the Cd elimination in these two species. A similar trend was observed for the mullet Mugil liza, in which a weak negative correlation ( $\mathrm{r}=-0.82)$ was found between the $\mathrm{Cd}$ concentrations in the liver and those in bile, revealing that $\mathrm{Cd}$ is eliminated from the liver through biliary excretion (Hauser-Davis et al., 2012a). Despite the similarity between the biliary Cd concentrations found in the present study and those from other species (Table 3), 50 days were necessary to observe a significant decrease of the Cd concentration in the liver of our two species following dietary consumption of the highest dose. This time interval is higher than that observed for other species, in which the hepatic $\mathrm{Cd}$ amount can decrease after 10 days of depuration for similar exposures (Kim et al., 2004, 2006). This difference might be a side effect of the temperature decrease during our experiments, which may have inhibited $\mathrm{Cd}$ elimination by reducing the metabolism of the fish. Hepatic $\mathrm{Cd}$ decreases were not linear during the depuration period, which might reflect $\mathrm{Cd}$ release from other tissues (not analysed in this study) to the liver before final biliary excretion. Depuration in experiment one was only conducted for 30 days, so we cannot conclude if effective Cd elimination would occur in the liver at the lowest exposure dose after a longer depuration period. However, the exposure dose used in the second experiment (i.e., $25 \mathrm{ppm} \mathrm{dw}$ ) constituted the threshold from which effective $\mathrm{Cd}$ elimination occurred after 30 days in the liver of rockfish (Kim et al., 2006). Although the opposite was observed in the grunt Terapon jarbua (Long and Wang, 2005a), this result 
suggests that an increase of the dietary exposure dose will increase the efflux rate in the liver of these species.

To our knowledge, only one study has investigated the link between Cd elimination and MT levels in fish. Long and Wang in 2005a found a negative correlation between the MT concentrations and Cd efflux rate in the whole body of T. jarbua. However, individuals were pre-exposed to waterborne or dietary $\mathrm{Ag}$ and $\mathrm{Cu}$ for 1 week, making it difficult to compare their results with our study. MT seem to be involved in metal elimination in fish, as shown in the Nile Tilapia Oreochromis niloticus exposed to copper, where an increase of the MT concentration in bile but not in the liver was observed (Hauser-Davis et al., 2014). The authors also found more MT-bound metal in the bile of exposed fish, confirming that MT constitute a vector for metal biliary excretion. This is in accordance with the higher biliary excretion (i.e., higher percentage of hepatic $\mathrm{Cd}$ in the sea bass bile; Fig. 5) and suggests that the greater basal MT pool in sea bass led to a higher amount of metal bound to MT, which enhanced Cd biliary excretion.

\section{- Cd relocation to muscle}

Cd elimination from the liver is also due to relocation to other tissues, such as muscle, through release into the general circulation. As in the liver, the Cd concentrations in muscle increased with exposure dose for both species in our study. Once relocated to muscle, Cd was globally not significantly eliminated from muscle during the depuration period and remained at the same level as at the end of the exposure period for both species. The same pattern has been observed in other fish species, for which Cd elimination has been shown to occur for all tissues investigated except the kidney and muscle (Kim et al., 2004, 2006). This observation of $\mathrm{Cd}$ retention in muscle leads to sanitary concerns since muscle represents the edible part of fish.

In sea bass, muscle accumulation occurred earlier and represented a higher proportion of hepatic $\mathrm{Cd}$ for both exposure doses (Fig. 1 and 5). This indicates that after digestion, Cd was transported from the liver to muscle more quickly and at larger proportions in sea bass. These observations may suggest a major transport of MT-bound Cd from hepatocytes to other tissues trough blood as observed in mammals (Chan et al., 1993). However, Cd/MT complexes were retrieved in kidney which is a secretory organ, contrary to muscle which constitutes a long-time storage compartment. It is thus more likely to be the result of faster cellular turnover in the muscle of sea bass due to its swimming behaviour, implying a higher amino acid or protein requirement to which $\mathrm{Cd}$ might be bound in the blood plasma, although 
the results of the present study do not formally prove it. Mobility seems to constitute a trait that determines metal repartition, leading to higher muscular contamination in vagile species vs sedentary ones. Even if the Cd concentrations in sea bass muscle after a two-month exposure were below the current maximum acceptable limit for seafood set by the European Union, the present study noted some concerns about health safety regarding consumption of flesh from highly swimming species. This hypothesis could furthermore constitute a new key for comprehension of the high $\mathrm{Cd}$ amounts frequently observed in muscle of some pelagic predator fish, such as swordfish and tunas (Araújo and Cedeño-Macias, 2016; Kojadinovic et al., 2007), despite the lack of Cd biomagnification along the trophic chain (Mathews et al., 2008; Mathews and Fisher, 2008).

\section{Conclusion}

European sea bass Dicentrarchus labrax and Senegalese sole Solea senegalensis exposed for two months to two environmentally realistic dietary $\mathrm{Cd}$ doses presented different accumulation kinetics. The first exposure (3.5 ppm dw) resulted in significant accumulation in the muscle and liver of both species, but the Cd levels increased earlier in sea bass. Biliary excretion of metal only occurred for sea bass at the end of the one-month depuration period. With a higher exposure dose (22.9 ppm dw), significant accumulation also occurred in the liver as in the muscle of the two species. While the $\mathrm{Cd}$ amounts remained constant in muscle, the liver showed significant metal elimination after two months of depuration, coinciding with effective biliary excretion in the two fish. Meanwhile, sea bass presented a higher accumulation rate at the highest exposure dose as well as higher biliary excretion in both experiments. MT concentrations varied over time, but were not influenced by metal exposure, calling into question the relevance MT for use as a biomarker of contamination. The basal MT pools were always greater in sea bass. Among other physiological factors, this specific characteristic, coupled with or influencing accumulation kinetics, helps to explain the interspecific variability in terms of the metal concentrations observed in fish from marine environments, such as the Canary Current Large Marine Ecosystem. 


\section{Acknowledgements}

The authors thank greatly Dr Emilien Pousse for the design of the graphical abstract, and Jean Raffray for the dissection of the fish. This study benefited of the technical support of the Centre of Documentation, Research and Experimentation on Accidental Water Pollution (CEDRE). This work was financially supported by the French National Research Agency project ANR-11-CEPL-0005 EPURE.

\section{References}

Ackerman, P.A., Morgan, J.D., Iwama, G.K., 2005. Les anésthésiques, 1-25.

Adam, V., Fabrik, I., Kizek, R., Adam, V., Eckschlager, T., Stiborova, M., Trnkova, L., 2010. Vertebrate metallothioneins as target molecules for analytical techniques. TrAC Trends in Analytical Chemistry 29, 409-418. doi:10.1016/j.trac.2010.02.004

Araújo, C.V.M., Cedeño-Macias, L.A., 2016. Heavy metals in yellowfin tuna (Thunnus albacares) and common dolphinfish (Coryphaena hippurus) landed on the Ecuadorian coast. Science of The Total Environment 541, 149-154. doi:10.1016/j.scitotenv.2015.09.090

Auger, P.A., Machu, E., Gorgues, T., Grima, N., Waeles, M., 2015. Comparative study of potential transfer of natural and anthropogenic cadmium to plankton communities in the North-West African upwelling. Science of The Total Environment 505, 870-888. doi:10.1016/j.scitotenv.2014.10.045

Barhoumi, S., MESSAOUDI, I., DELI, T., SAÏD, K., KERKENI, A., 2009. Cadmium bioaccumulation in three benthic fish species, Salaria basilisca, Zosterisessor ophiocephalus and Solea vulgaris collected from the Gulf of Gabes in Tunisia. Journal of Environmental Sciences 21, 980-984. doi:10.1016/S1001-0742(08)62371-2

Beg, M.U., Al-Jandal, N., Al-Subiai, S., Karam, Q., Husain, S., Butt, S.A., Ali, A., Al-Hasan, E., Al-Dufaileej, S., Al-Husaini, M., 2015. Metallothionein, oxidative stress and trace metals in gills and liver of demersal and pelagic fish species from Kuwaits' marine area. Marine Pollution Bulletin, An Ecological Assessment of Kuwait's Marine Environment 100, 662-672. doi:10.1016/j.marpolbul.2015.07.058

Berntssen, M.H.G., Aspholm, O.Ø., Hylland, K., Wendelaar Bonga, S.E., Lundebye, A.-K., 2001. Tissue metallothionein, apoptosis and cell proliferation responses in Atlantic salmon (Salmo salar L.) parr fed elevated dietary cadmium. Comparative Biochemistry and Physiology Part C: Toxicology \& Pharmacology 128, 299-310. doi:10.1016/S1532-0456(00)00204-0

Bodin, N., N'Gom-Kâ, R., Kâ, S., Thiaw, O.T., Tito de Morais, L., Le Loc'h, F., RozuelChartier, E., Auger, D., Chiffoleau, J.-F., 2013. Assessment of trace metal contamination in mangrove ecosystems from Senegal, West Africa. Chemosphere 90, 150-157. doi:10.1016/j.chemosphere.2012.06.019

Chahid, A., Hilali, M., Benlhachimi, A., Bouzid, T., 2014. Contents of cadmium, mercury and lead in fish from the Atlantic sea (Morocco) determined by atomic absorption spectrometry. Food Chemistry 147, 357-360. doi:10.1016/j.foodchem.2013.10.008

Cheung, A.P.L., Lam, T.H.-J., Chan, K.M., 2004. Regulation of Tilapia metallothionein gene expression by heavy metal ions. Marine Environmental Research, Twelfth 
International Symposium on Pollutant Responses in Marine Organisms 58, 389-394. doi:10.1016/j.marenvres.2004.03.084

Chowdhury, M.J., Baldisserotto, B., Wood, C.M., 2005. Tissue-Specific Cadmium and Metallothionein Levels in Rainbow Trout Chronically Acclimated to Waterborne or Dietary Cadmium. Arch Environ Contam Toxicol 48, 381-390. doi:10.1007/s00244004-0068-2

Creighton, N., Twining, J., 2010. Bioaccumulation from food and water of cadmium, selenium and zinc in an estuarine fish, Ambassis jacksoniensis. Marine Pollution Bulletin 60, 1815-1821. doi:10.1016/j.marpolbul.2010.05.025

Cretì, P., Trinchella, F., Scudiero, R., 2009. Heavy metal bioaccumulation and metallothionein content in tissues of the sea bream Sparus aurata from three different fish farming systems. Environ Monit Assess 165, 321-329. doi:10.1007/s10661-0090948-Z

Dallinger, R., Egg, M., Köck, G., Hofer, R., 1997. The role of metallothionein in cadmium accumulation of Arctic char (Salvelinus alpinus) from high alpine lakes. Aquatic Toxicology 38, 47-66. doi:10.1016/S0166-445X(96)00840-5

Dang, F., Wang, W.-X., 2009. Assessment of tissue-specific accumulation and effects of cadmium in a marine fish fed contaminated commercially produced diet. Aquatic Toxicology 95, 248-255. doi:10.1016/j.aquatox.2009.09.013

Danion, M., Le Floch, S., Kanan, R., Lamour, F., Quentel, C., 2011. Effects of in vivo chronic hydrocarbons pollution on sanitary status and immune system in sea bass (Dicentrarchus labrax L.). Aquatic Toxicology 105, 300-311. doi:10.1016/j.aquatox.2011.06.022

Diop, C., Dewaelé, D., Cazier, F., Diouf, A., Ouddane, B., 2015. Assessment of trace metals contamination level, bioavailability and toxicity in sediments from Dakar coast and Saint Louis estuary in Senegal, West Africa. Chemosphere. doi:10.1016/j.chemosphere.2014.12.041

Diop, C., Dewaelé, D., Diop, M., Touré, A., Cabral, M., Cazier, F., Fall, M., Diouf, A., Ouddane, B., 2014. Assessment of contamination, distribution and chemical speciation of trace metals in water column in the Dakar coast and the Saint Louis estuary from Senegal, West Africa. Marine Pollution Bulletin. doi:10.1016/j.marpolbul.2014.06.051Diop, M., Amara, R., 2016. Mercury concentrations in the coastal marine food web along the Senegalese coast. Environ Sci Pollut Res 23, 11975-11984. doi:10.1007/s11356-016-6386-x

Diop, M., Howsam, M., Diop, C., Cazier, F., Goossens, J.F., Diouf, A., Amara, R., 2016. Spatial and seasonal variations of trace elements concentrations in liver and muscle of round Sardinelle (Sardinella aurita) and Senegalese sole (Solea senegalensis) along the Senegalese coast. Chemosphere $144, \quad 758-766$. doi:10.1016/j.chemosphere.2015.08.085

El Morhit, M., Belghity, D., El Morhit, A., 2013. Metallic contaminnation in muscle of three fish species in the southern Atlantic coast at Laayoune (Morocco). LARHYSS Journal ISSN 1112-3680.

Fernandes, D., Bebianno, M.J., Porte, C., 2008. Hepatic levels of metal and metallothioneins in two commercial fish species of the Northern Iberian shelf. Science of The Total Environment 391, 159-167. doi:10.1016/j.scitotenv.2007.10.057

Fernandes, D., Porte, C., Bebianno, M.J., 2007. Chemical residues and biochemical responses in wild and cultured European sea bass (Dicentrarchus labrax L.). Environmental Research 103, 247-256. doi:10.1016/j.envres.2006.05.015

Fonseca, V.F., França, S., Serafim, A., Company, R., Lopes, B., Bebianno, M.J., Cabral, H.N., 2011. Multi-biomarker responses to estuarine habitat contamination in three fish 
species: Dicentrarchus labrax, Solea senegalensis and Pomatoschistus microps. Aquatic Toxicology 102, 216-227. doi:10.1016/j.aquatox.2011.01.018

Fu, H., Steinebach, O.M., van den Hamer, C.J.A., Balm, P.H.M., Lock, R.A.C., 1990. Involvement of cortisol and metallothionein-like proteins in the physiological responses of tilapia (Oreochromis mossambicus) to sublethal cadmium stress. Aquatic Toxicology 16, 257-269. doi:10.1016/0166-445X(90)90040-V

Gaudry, A., Zeroual, S., Gaie-Levrel, F., Moskura, M., Boujrhal, F.Z., El Moursli, R.C., Guessous, A., Mouradi, A., Givernaud, T., Delmas, R., 2007. Heavy Metals Pollution of the Atlantic Marine Environment by the Moroccan Phosphate Industry, as Observed through their Bioaccumulation in Ulva Lactuca. Water, Air, \& Soil Pollution 178, 267-285.

George, S.G., Todd, K., Wright, J., 1996. Regulation of metallothionein in teleosts: Induction of MTmRNA and protein by cadmium in hepatic and extrahepatic tissues of a marine flatfish, the turbot (Scophthalmus maximus). Comparative Biochemistry and Physiology Part C: Pharmacology, Toxicology and Endocrinology 113, 109-115. doi:10.1016/0742-8413(95)02076-4

Goutte, A., Cherel, Y., Churlaud, C., Ponthus, J.-P., Massé, G., Bustamante, P., 2015. Trace elements in Antarctic fish species and the influence of foraging habitats and dietary habits on mercury levels. Science of The Total Environment 538, 743-749. doi:10.1016/j.scitotenv.2015.08.103

Guinot, D., Ureña, R., Pastor, A., Varó, I., Ramo, J. del, Torreblanca, A., 2012. Long-term effect of temperature on bioaccumulation of dietary metals and metallothionein induction in Sparus aurata. Chemosphere 87, 1215-1221. doi:10.1016/j.chemosphere.2012.01.020

Hauser-Davis, R.A., Bastos, F.F., de Oliveira, T.F., Ziolli, R.L., de Campos, R.C., 2012a. Fish bile as a biomarker for metal exposure. Marine Pollution Bulletin 64, 1589-1595. doi:10.1016/j.marpolbul.2012.05.017

Hauser-Davis, R.A., Bastos, F.F., Tuton, B., Chávez Rocha, R., Pierre, T.S., Ziolli, R.L., Arruda, M.A.Z., 2014. Bile and liver metallothionein behavior in copper-exposed fish. Journal of Trace Elements in Medicine and Biology 28, 70-74. doi:10.1016/j.jtemb.2013.09.003

Hauser-Davis, R.A., Campos, R.C. de, Ziolli, R.L., 2012b. Fish Metalloproteins as Biomarkers of Environmental Contamination, in: Whitacre, D.M. (Ed.), Reviews of Environmental Contamination and Toxicology Volume 218, Reviews of Environmental Contamination and Toxicology. Springer US, pp. 101-123. doi:10.1007/978-1-4614-3137-4_2

Haux, C., Larsson, А., 1984. Long-term sublethal physiological effects on rainbow trout, Salmo gairdneri, during exposure to cadmium and after subsequent recovery. Aquatic Toxicology 5, 129-142. doi:10.1016/0166-445X(84)90004-3

Hylland, K., Nissen-Lie, T., Christensen, P.G., Sandvik, M., 1998. Natural modulation of hepatic metallothionein and cytochrome P4501A in flounder, Platichthys flesus L. Marine Environmental Research, Pollutant Responses in Marine Organisms 46, 5155. doi:10.1016/S0141-1136(97)00059-7

Hyllner, S.J., Andersson, T., Haux, C., Olsson, P.-E., 1989. Cortisol induction of metallothionein in primary culture of rainbow trout hepatocytes. J. Cell. Physiol. 139, 24-28. doi:10.1002/jcp.1041390105

Jebali, J., Banni, M., Gerbej, H., Boussetta, H., López-Barea, J., Alhama, J., 2008. Metallothionein induction by $\mathrm{Cu}, \mathrm{Cd}$ and $\mathrm{Hg}$ in Dicentrarchus labrax liver: Assessment by RP-HPLC with fluorescence detection and spectrophotometry. Marine Environmental Research 65, 358-363. doi:10.1016/j.marenvres.2008.01.002 
Jeffree, R.A., Warnau, M., Teyssié, J.-L., Markich, S.J., 2006. Comparison of the bioaccumulation from seawater and depuration of heavy metals and radionuclides in the spotted dogfish Scyliorhinus canicula (Chondrichthys) and the turbot Psetta maxima (Actinopterygii: Teleostei). Science of The Total Environment 368, 839-852. doi:10.1016/j.scitotenv.2006.03.026

Kalman, J., Riba, I., Ángel DelValls, T., Blasco, J., 2010. Comparative toxicity of cadmium in the commercial fish species Sparus aurata and Solea senegalensis. Ecotoxicology and Environmental Safety 73, 306-311. doi:10.1016/j.ecoenv.2009.10.013

Kim, S.G., Eom, K.-H., Kim, S.-S., Jin, H.-G., Kang, J.-C., 2006. Kinetics of Cd accumulation and elimination in tissues of juvenile rockfish (Sebastes schlegeli) exposed to dietary Cd. Marine Environmental Research 62, 327-340. doi:10.1016/j.marenvres.2006.05.001

Kim, S.-G., Jee, J.-H., Kang, J.-C., 2004. Cadmium accumulation and elimination in tissues of juvenile olive flounder, Paralichthys olivaceus after sub-chronic cadmium exposure. Environmental Pollution 127, 117-123. doi:10.1016/S0269-7491(03)00254-9

Kiszka, J.J., Aubail, A., Hussey, N.E., Heithaus, M.R., Caurant, F., Bustamante, P., 2015. Plasticity of trophic interactions among sharks from the oceanic south-western Indian Ocean revealed by stable isotope and mercury analyses. Deep Sea Research Part I: Oceanographic Research Papers 96, 49-58. doi:10.1016/j.dsr.2014.11.006

Kojadinovic, J., Potier, M., Le Corre, M., Cosson, R.P., Bustamante, P., 2007. Bioaccumulation of trace elements in pelagic fish from the Western Indian Ocean. Environmental Pollution, Lichens in a Changing Pollution Environment 146, 548-566. doi:10.1016/j.envpol.2006.07.015

Le Croizier, G., Schaal, G., Gallon, R., Fall, M., Le Grand, F., Munaron, J.-M., Rouget, M.L., Machu, E., Le Loc'h, F., Laë, R., Tito de Morais, L., 2016. Trophic ecology influence on metal bioaccumulation in marine fish: Inference from stable isotope and fatty acid analyses. Science of The Total Environment 573, 83-95. doi:10.1016/j.scitotenv.2016.08.035

Long, A., Wang, W., 2005a. Metallothionein induction and bioaccumulation kinetics of Cd and $\mathrm{Ag}$ in the marine fish Terapon jarbua challenged with dietary or waterborne Ag and Cu. Mar Ecol Prog Ser 291, 215-226. doi:10.3354/meps291215

Long, A., Wang, W.-X., 2005b. Assimilation and bioconcentration of Ag and Cd by the marine black bream after waterborne and dietary metal exposure. Environmental Toxicology and Chemistry 24, 709-716. doi:10.1897/03-664.1

López, R., De Pontual, H., Bertignac, M., Mahévas, S., 2015. What can exploratory modelling tell us about the ecobiology of European sea bass (Dicentrarchus labrax): a comprehensive overview. Aquatic Living Resources, 28(2-4), 61-79. Publisher's official version: http://doi.org/10.1051/alr/2015007 , Open Access version: http://archimer.ifremer.fr/doc/00341/45258/

Maanan, M., 2008. Heavy metal concentrations in marine molluscs from the Moroccan coastal region. Environmental Pollution 153, 176-183. doi:10.1016/j.envpol.2007.07.024

Mathews, T., Fisher, N., Jeffree, R., Teyssié, J., 2008. Assimilation and retention of metals in teleost and elasmobranch fishes following dietary exposure. Marine Ecology Progress Series 360, 1-12. doi:10.3354/meps07462

Mathews, T., Fisher, N.S., 2009. Dominance of dietary intake of metals in marine elasmobranch and teleost fish. Science of The Total Environment 407, 5156-5161. doi:10.1016/j.scitotenv.2009.06.003

Mathews, T., Fisher, N.S., 2008. Trophic transfer of seven trace metals in a four-step marine food chain. Mar Ecol Prog Ser 367, 23-33. doi:10.3354/meps07536 
McGeer, J.C., Niyogi, S., Scott Smith, D., 2011. 3 - Cadmium, in: Chris M. Wood, A.P.F. and C.J.B. (Ed.), Fish Physiology, Homeostasis and Toxicology of Non-Essential Metals. Academic Press, pp. 125-184.

Metian, M., Warnau, M., Chouvelon, T., Pedraza, F., Rodriguez y Baena, A.M., Bustamante, P., 2013. Trace element bioaccumulation in reef fish from New Caledonia: Influence of trophic groups and risk assessment for consumers. Marine Environmental Research 87-88, 26-36. doi:10.1016/j.marenvres.2013.03.001

Mieiro, C.L., Bervoets, L., Joosen, S., Blust, R., Duarte, A.C., Pereira, M.E., Pacheco, M., 2011. Metallothioneins failed to reflect mercury external levels of exposure and bioaccumulation in marine fish - Considerations on tissue and species specific responses. Chemosphere 85, 114-121. doi:10.1016/j.chemosphere.2011.05.034

Ng, T. Y. T., \& Wood, C. M., 2008. Trophic transfer and dietary toxicity of Cd from the oligochaete to the rainbow trout. Aquatic toxicology, 87(1), 47-59.

Official Journal of the European Union, 2014. Commission Regulation (EU) No 488/2014 of 12 May 2014 amending Regulation (EC) No 1881/2006 as regards maximum levels of cadmium in foodstuff s.

R Core Team (2016). R: A language and environment for statistical computing. R Foundation for Statistical Computing, Vienna, Austria. URL https://www.R-project.org/

Roméo, M., Cosson, R.P., Gnassia-Barelli, M., Risso, C., Stien, X., Lafaurie, M., 1997. Metallothionein determination in the liver of the sea bass Dicentrarchus labrax treated with copper and B(a)P. Marine Environmental Research 44, 275-284. doi:10.1016/S0141-1136(97)00007-X

Roméo, M., Siau, Y., Sidoumou, Z., Gnassia-Barelli, M., 1999. Heavy metal distribution in different fish species from the Mauritania coast. The Science of The Total Environment 232, 169-175. doi:10.1016/S0048-9697(99)00099-6

Salas-Leiton, E., Anguis, V., Martín-Antonio, B., Crespo, D., Planas, J.V., Infante, C., Cañavate, J.P., Manchado, M., 2010. Effects of stocking density and feed ration on growth and gene expression in the Senegalese sole (Solea senegalensis): Potential effects on the immune response. Fish \& Shellfish Immunology 28, 296-302. doi:10.1016/j.fsi.2009.11.006

Scudiero, R., Temussi, P.A., Parisi, E., 2005. Fish and mammalian metallothioneins: a comparative study. Gene, Structural Approaches to Sequence Evolution: Molecules, Networks, Populations - Part 1 345, 21-26. doi:10.1016/j.gene.2004.11.024

Sidoumou, Z., Gnassia-Barelli, M., Siau, Y., Morton, V., Roméo, M., 2005. Distribution and Concentration of Trace Metals in Tissues of Different Fish Species from the Atlantic Coast of Western Africa. Bulletin of Environmental Contamination and Toxicology 74, 988-995. doi:10.1007/s00128-005-0677-0

Siscar, Rosario, Koenig, S., Torreblanca, A., Solé, M., 2014. The role of metallothionein and selenium in metal detoxification in the liver of deep-sea fish from the NW Mediterranean Sea. Science of The Total Environment 466-467, 898-905. doi:10.1016/j.scitotenv.2013.07.081

Siscar, R., Torreblanca, A., del Ramo, J., Solé, M., 2014. Modulation of metallothionein and metal partitioning in liver and kidney of Solea senegalensis after long-term acclimation to two environmental temperatures. Environmental Research 132, 197205. doi:10.1016/j.envres.2014.04.020

Siscar, R., Torreblanca, A., Palanques, A., Solé, M., 2013. Metal concentrations and detoxification mechanisms in Solea solea and Solea senegalensis from NW Mediterranean fishing grounds. Marine Pollution Bulletin 77, 90-99. doi:10.1016/j.marpolbul.2013.10.026 
Teixeira, C.M., Cabral, H.N., 2010. Comparative analysis of the diet, growth and reproduction of the soles, <span class="italic" $>$ Solea solea $</$ span $>$ and $<$ span class $=$ "italic" $>$ Solea senegalensis $</$ span $>$, occurring in sympatry along the Portuguese coast. Journal of the Marine Biological Association of the United Kingdom 90, 9951003. doi:10.1017/S0025315410000238

Tenório-Daussat, C.L., Resende, M.C.M., Ziolli, R.L., Hauser-Davis, R.A., Schaumloffel, D., Saint'Pierre, T.D., 2014. Evaluation and standardization of different purification procedures for fish bile and liver metallothionein quantification by spectrophotometry and SDS-PAGE analyses. Talanta 120, 491-497. doi:10.1016/j.talanta.2013.11.070

Tort, L., Kargacin, B., Torres, P., Giralt, M., Hidalgo, J., 1996. The effect of cadmium exposure and stress on plasma cortisol, metallothionein levels and oxidative status in rainbow trout (Oncorhynchus mykiss) liver. Comparative Biochemistry and Physiology Part C: Pharmacology, Toxicology and Endocrinology 114, 29-34. doi:10.1016/0742-8413(95)02107-8

Wang, W.-X., Onsanit, S., Dang, F., 2012. Dietary bioavailability of cadmium, inorganic mercury, and zinc to a marine fish: Effects of food composition and type. Aquaculture 356-357, 98-104. doi:10.1016/j.aquaculture.2012.05.031

$\mathrm{Xu}$, Y., \& Wang, W. X., 2002. Exposure and potential food chain transfer factor of Cd, Se and $\mathrm{Zn}$ in marine fish Lutjanus argentimaculatus. Marine Ecology Progress Series, 238, 173-186.Zhang, L., Wang, W.-X., 2007a. Waterborne cadmium and zinc uptake in a euryhaline teleost Acanthopagrus schlegeli acclimated to different salinities. Aquatic Toxicology, A Tribute to Rick Playle: The Interface of Toxicology, Physiology, and Modeling in Improving Water Quality Regulations for MetalsProceedings of a Symposium: "SETAC 27th Annual Meeting. A Tribute to Rick Playle: The Interface of Toxicology, Physiology, and Modeling in Improving Water Quality Regulations for Metals" 84, 173-181. doi:10.1016/j.aquatox.2007.03.027

Zhang, L., Wang, W.-X., 2007b. Gastrointestinal uptake of cadmium and zinc by a marine teleost Acanthopagrus schlegeli. Aquatic Toxicology 85, 143-153. doi:10.1016/j.aquatox.2007.08.008 


\section{Figures}
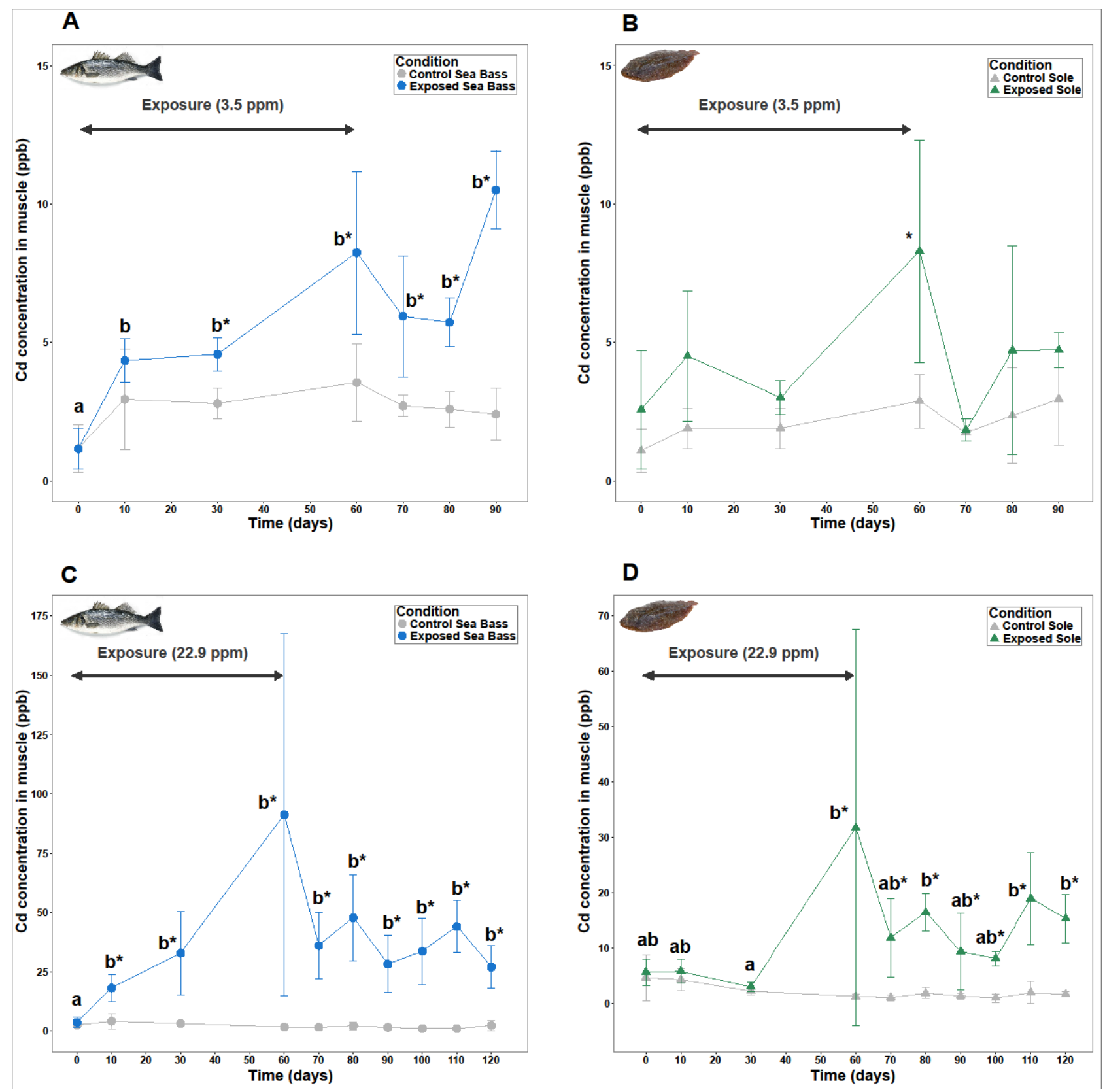

Figure 1: Cd concentrations (mean \pm standard deviation; $n g \cdot \mathrm{g}^{-1}$ dry wt) in the muscle of the Sea bass (blue) and the Sole (green) during experiment one (3.5 ppm Cd exposure; A and B) and experiment two (22.9 ppm Cd exposure; $\mathrm{C}$ and D). Different letters indicate significant differences over time among exposed fish (ANOVAs followed by Tukey's HSD tests). “*” indicates significant differences between exposed and control fish for a same sampling point (ANOVAs). 


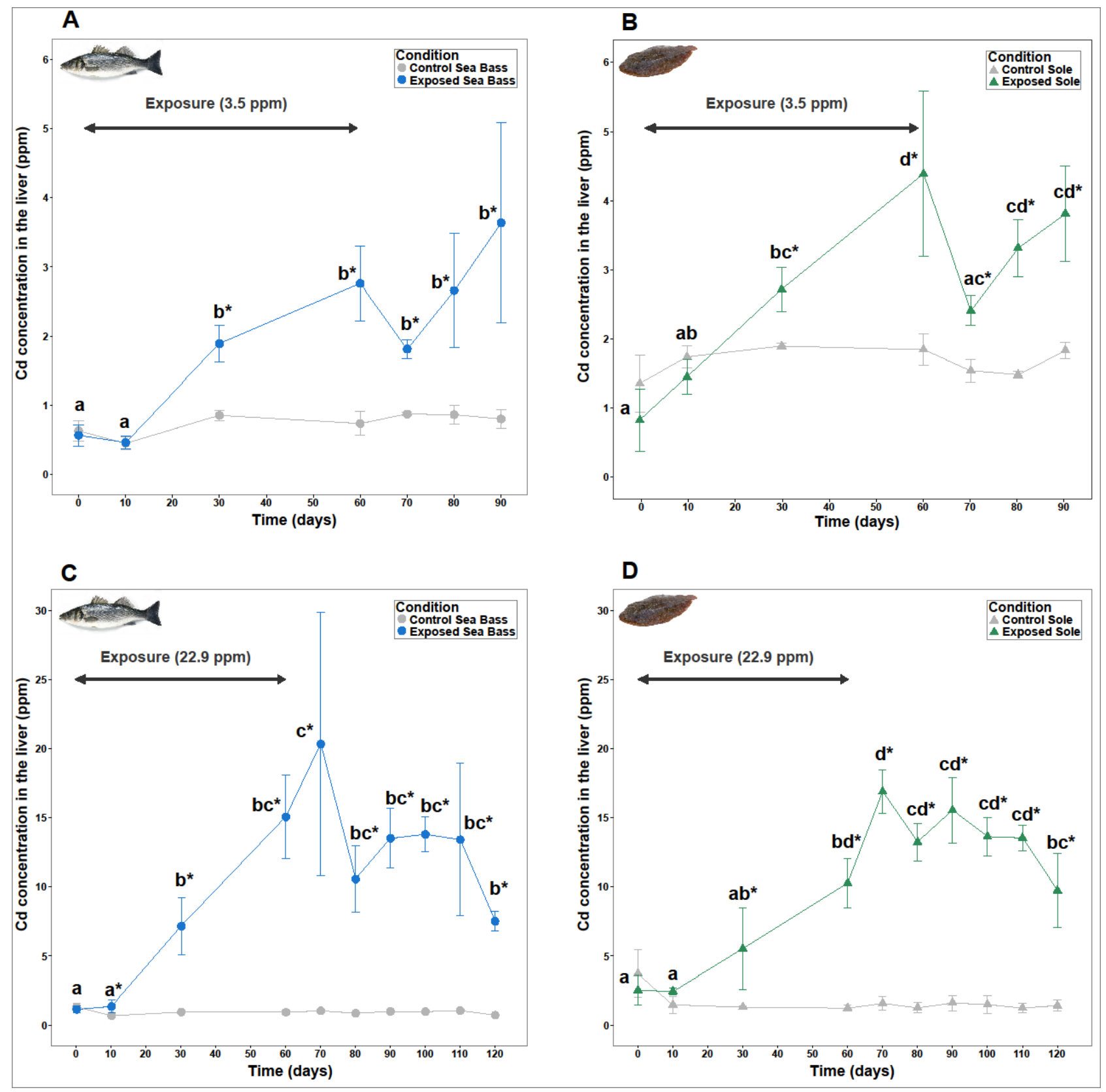

Figure 2: Cd concentrations (mean \pm standard deviation; $\mu \mathrm{g} \cdot \mathrm{g}^{-1}$ dry wt) in the liver of the Sea bass (blue) and the Sole (green) during experiment one (3.5 ppm Cd exposure; A and B) and experiment two (22.9 ppm Cd exposure; C and D). Different letters indicate significant differences over time among exposed fish (ANOVAs followed by Tukey's HSD tests). “*” indicates significant differences between exposed and control fish for a same sampling point (ANOVAs). 


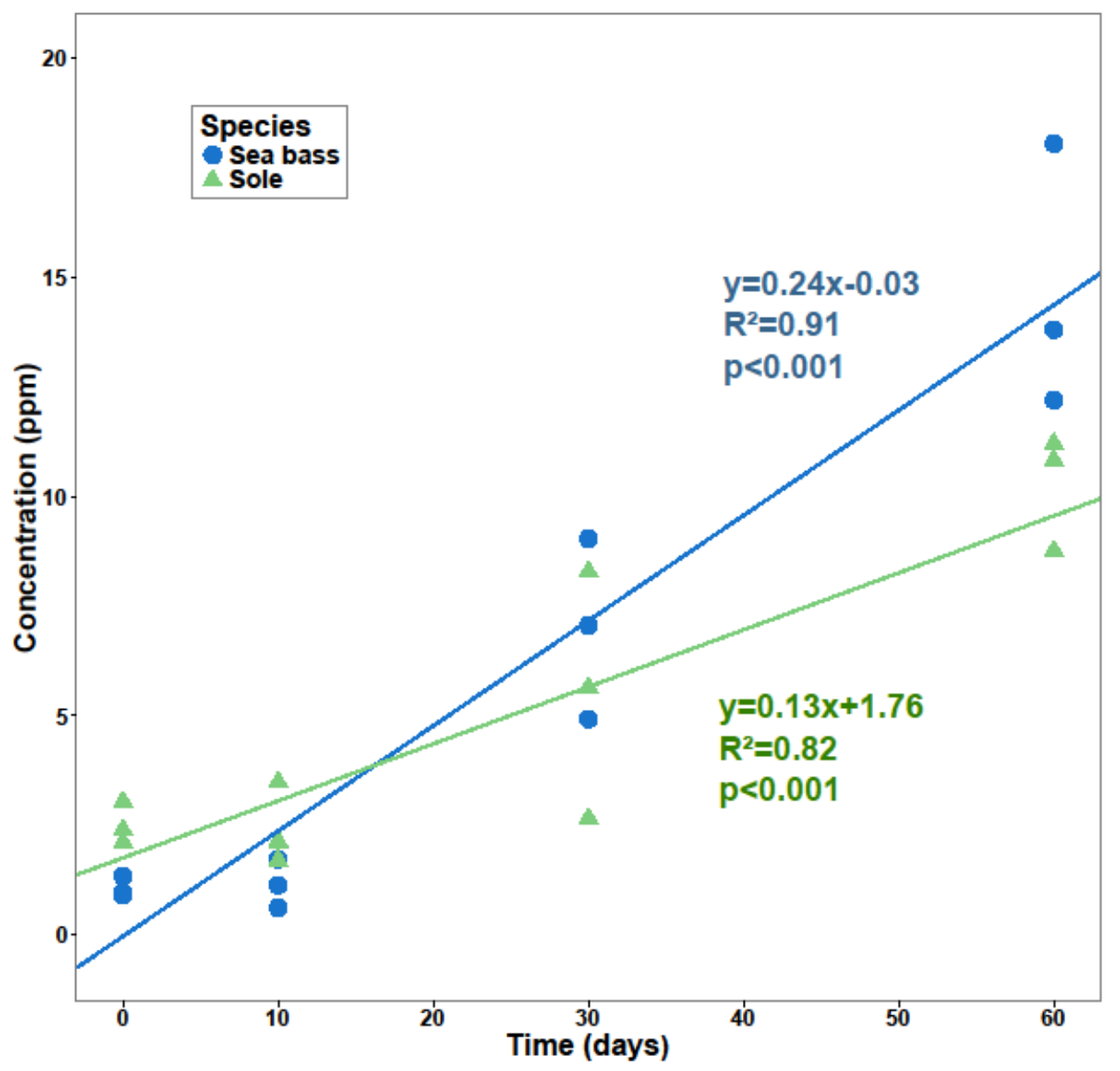

Figure 3: Cd concentrations $\left(\mu \mathrm{g} \cdot \mathrm{g}^{-1} \mathrm{dry} \mathrm{wt}\right.$ ) in the liver of the Sea bass and the Sole during 60 days of exposure to $22.9 \mathrm{ppm}$ of $\mathrm{Cd}$. Slopes of the linear regression curves represent the accumulation rate $\left(k_{\mathrm{a}}\right)$. 

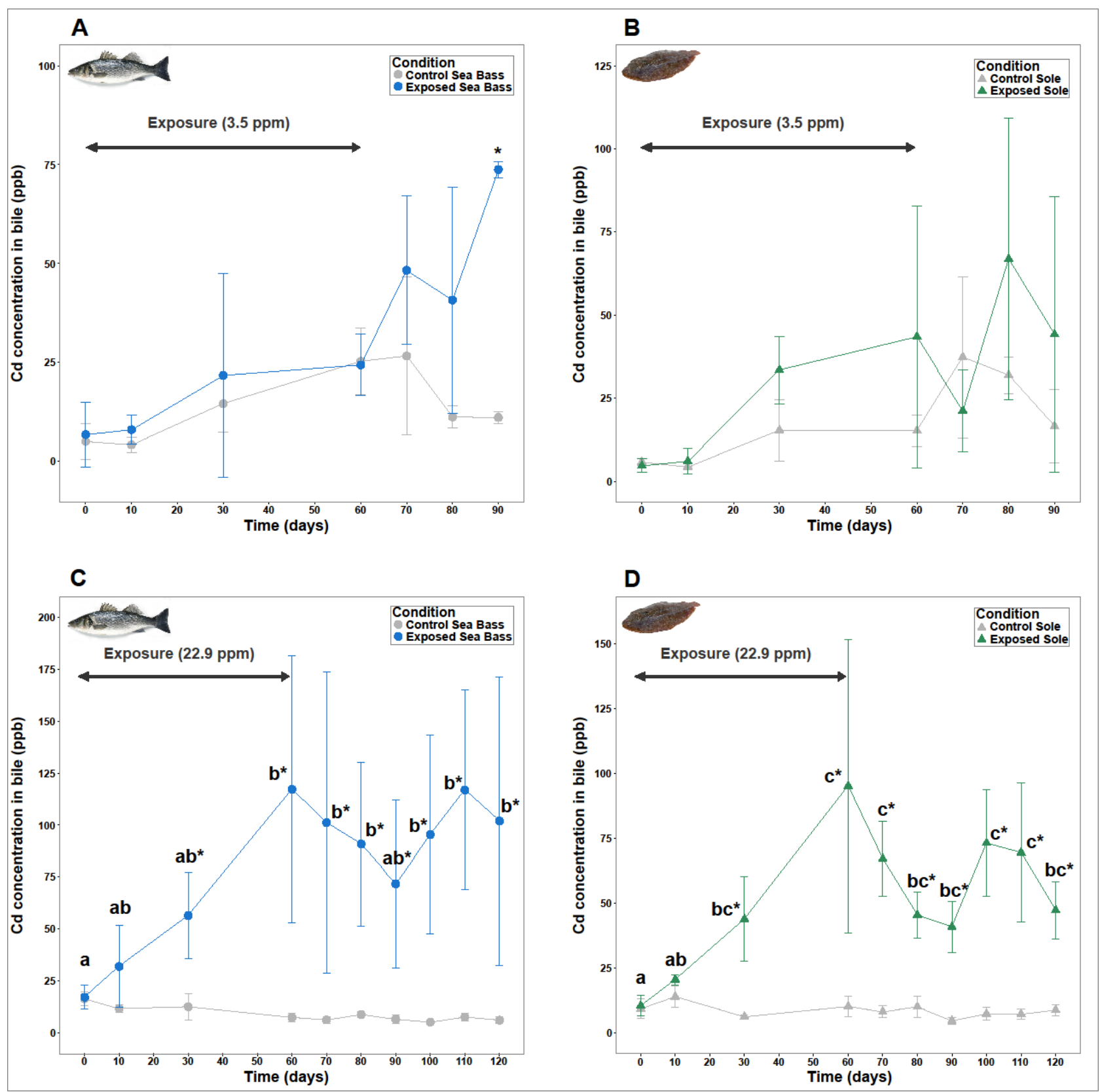

Figure 4: Cd concentrations (mean \pm standard deviation; $n g \cdot \mathrm{g}^{-1}$ dry wt) in the bile of the Sea bass (blue) and the Sole (green) during experiment one (3.5 ppm Cd exposure; $\mathrm{A}$ and $\mathrm{B}$ ) and experiment two (22.9 ppm Cd exposure; C and D). Different letters indicate significant differences over time among exposed fish (ANOVAs followed by Tukey's HSD tests). “*” indicates significant differences between exposed and control fish for a same sampling point (ANOVAs). 


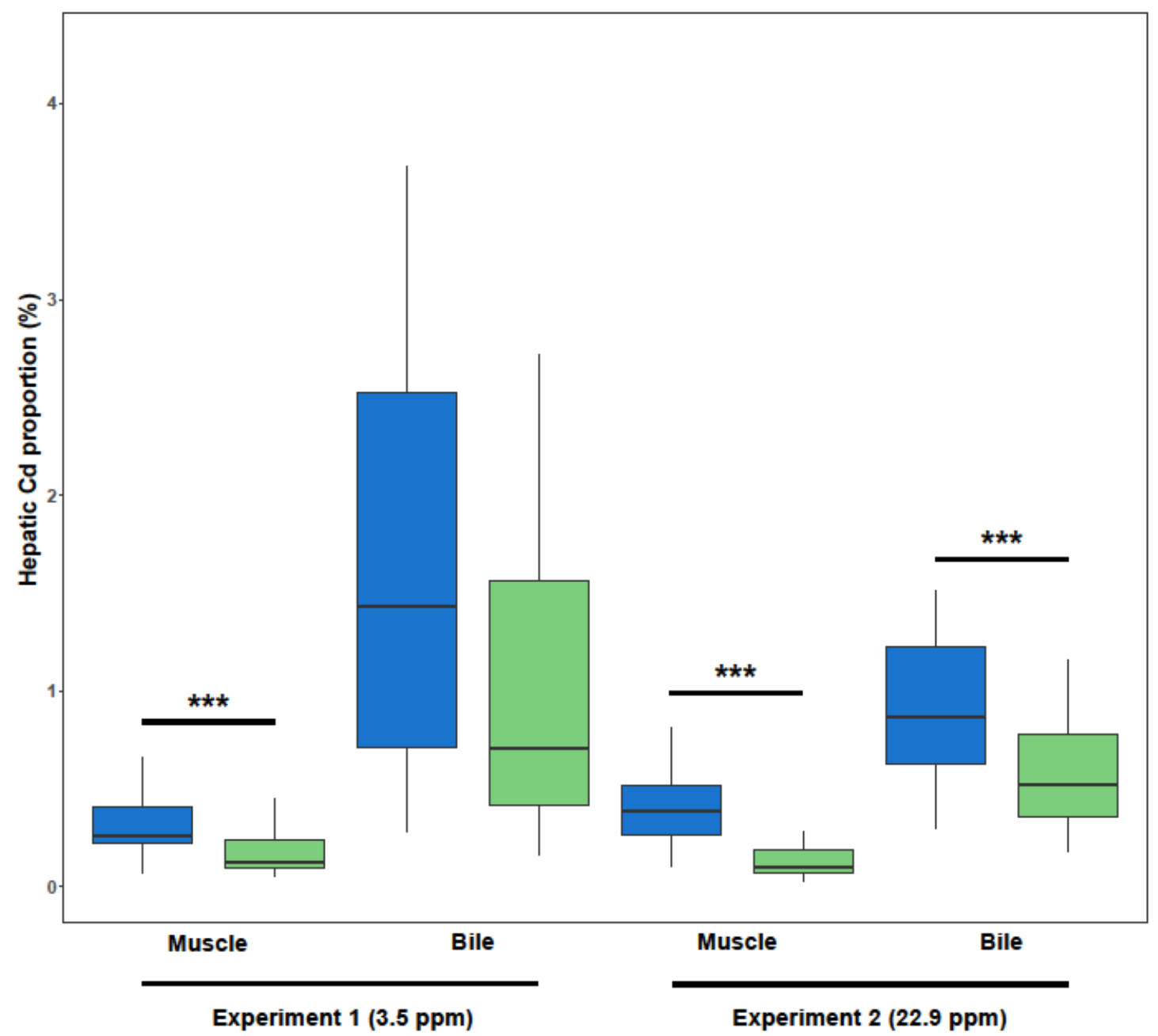

Figure 5: Proportion of hepatic Cadmium transported to muscle or excreted through bile (i.e. percentage of the ratio of liver $\mathrm{Cd}$ concentration on muscle or bile $\mathrm{Cd}$ concentration) calculated during the entire experiment. The upper and lower hinges represent the quartiles, the vertical lines, the maximum and minimum data values and the bold line represents the median value. Values are shown for the Sea bass (blue) and the Sole (green) during the two experiments. "**" indicates significant differences between exposed and control fish for a same sampling point (ANOVAs). 

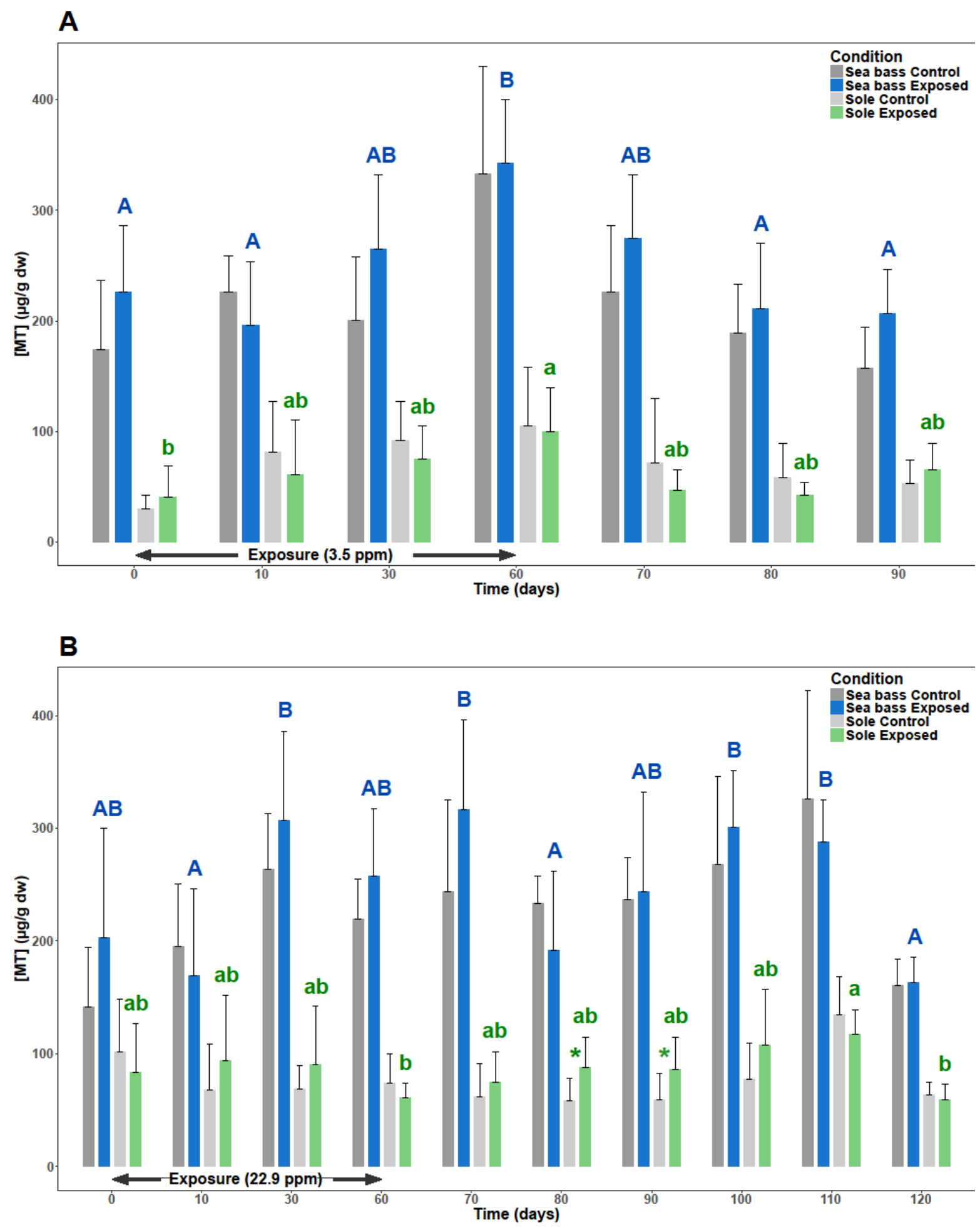

Figure 6: Metallothionein concentrations (mean \pm standard deviation; $\mu \mathrm{g} \cdot \mathrm{g}^{-1}$ dry wt) in the Sea bass and the Sole liver during experiment one (3.5 $\mathrm{Cd}$ exposure; upper figure) and experiment two (22.9 ppm exposure; lower figure. Different letters indicate significant differences over time among exposed fish of a same species; “*” indicates significant differences between control and exposed fish of a same species; MT concentrations were always higher in Sea bass than in Sole regardless of time and condition except at T0 and T10 during experiment two (ANOVAs followed by Tukey's HSD tests). 